DOI: https://doi.org/10.31073/abg.59.06

\title{
VARIABILITY AND HEREDITY OF THE BULL`S BREEDING VALUE OF DIFFERENT GENEALOGICAL FORMATIONS OF THE HOLSTEIN BREED
}

\author{
A. P. KRUGLIAK, T. O. KRUGLIAK \\ Institute of Animal Breeding and Genetics nd. a. M.V.Zubets of NAAS (Chubynske, Ukraine) \\ https://orcid.org/0000-0002-1512-6576 - А. П. Кругляк \\ https://orcid.org/0000-0002-8410-3191 - T. О. Кругляк \\ bulochka23@ukr.net
}

The results of analytical studies of breeding value variability on the basis of milk productivity, selected for reproduction of bulls of different genealogical formations of Holstein breed, are presented. A statistically significant difference between the breeding value of bulls and their parents of different genealogical groups of the milk yield was established.

The variability of bulls breeding traits and the milk productivity of their daughters in the middle of genealogical formations was dominated by similar indicators between genealogical formations.

In the middle of related genealogical formations, animals of new generations significantly outnumbered animals of earlier generations in level of breeding value.

The high correlation between breeding value of milk yield, milk fat and protein of parents and their sons was identified. The highest correlation coefficient $(r=+0.643 \pm 0.030)$ was established between the absolute milk productivity of daughters for 305 days of first lactation and the level of breeding value of milk yield of their parents, which decreased sharply when compared with their ancestors of older generations.

The power of the influence of ancestral breeding value on the milk yield of the first born cows decreased with the removal of them in generations. The share of fathers influence on the daughter's milk yield was $35.1 \%$, fathers - fathers $-11.7 \%$, mothers $-10.6 \%$ and fathers - fathers - fathers $2.7 \%$.

Keywords: bull, genealogical group, breeding value, milk productivity, variability, correlation, heredity, power of influence

\section{МІНЛИВІСТЬ ТА УСПАДКУВАННЯ ПЛЕМІННОЇ ЦІННОСТІ БУГАЇВ РІЗНИХ ГЕНЕАЛОГІЧНИХ ФОРМУВАНЬ ГОЛШТИНСЬКОЇ ПОРОДИ}

\section{А. П. Кругляк, Т. О. Кругляк}

Інститут розведення і генетики тварин імені М.В.Зубия НААН (Чубинське, Україна)

Викладено результати аналітичних досліджень мінливості племінної ичінності за ознаками молочної продуктивності, відселекиіонованих для відтворення бугаїв різних генеалогічних формувань голштинської породи. Встановлено статистично вірогідну різницю між показниками племінної цінності бугаїв та їхніх батьків різних генеалогічних формувань за на$\partial o \epsilon M$.

Мінливість ознак племінної цінності бугаїв та молочної продуктивності їхніх дочок в середині генеалогічних формувань переважала аналогічні показники між генеалогічними формуваннями.

В середині споріднених генеалогічних формувань тварини нових поколінь за рівнем племінної иінності суттєво переважали тварин попередніх поколінь.

Визначено високі кореляційні зв'язки між рівнем племінної цінності за надоєм, молочним жиром та білком батьків та їхніх синів. Найвищий коефіџієнт корелящії $(r=+0,643 \pm 0,030)$ встановлено між показниками молочної продуктивності дочок за 305 днів першої лактації 
та рівнем племінної иінності за надоєм їхніх батьків, який різко знижувався при порівнянні їх із предками старших поколінь.

Сила впливу племінної цінності предків на надій первісток зменшувалась із віддаленням ї у поколіннях. Частка впливу батьків на надій дочок становила 35,1\%, батьків - батьків 11,7\%, матерів - 10,6\% та батьків - батьків - батьків-2,7\%.

Ключові слова: бугай, споріднена група, племінна цінність, молочна продуктивність, мінливість, кореляція, успадкування, сила впливу

\section{ИЗМЕНЧИВОСТЬ И НАСЛЕДОВАНИЕ ПЛЕМЕННОЙ ЦЕННОСТИ БЫКОВ РАЗНЫХ ГЕНЕАЛОГИЧЕСКИХ ФОРМИРОВАНИЙ ГОЛШТИНСКОЙ ПОРОДЫ}

\section{А. П. Кругляк, Т. А. Кругляк}

Институт разведения и генетики животных имени М.В.Зубиа НААН (Чубинское, Украина)

Изложены результаты аналитических исследований изменчивости племенной ценности по признакам молочной продуктивности, отселекиионированных для воспроизведения быков различных генеалогических формирований голштинской породы. Установлено статистически достоверную разнииу между показателями племенной цеености быков и их родителей разных генеалогических формирований по надою.

Изменчивость признаков племенной ценности быков и молочной продуктивности дочерей в середине генеалогических формирований была большей, чем аналогичные показатели между генеалогическими формированиями.

В середине родственных генеалогических формирований животные новых поколений по уровню племенной цеенности существенно преобладали животных предылущих поколений.

Установлена высокая корреляциионная связь между уровнем племенной ценности по надою, молочному жиру и белку родителей и их сыновей. Самый высокий коэффициент коррелящии $(r=+0,643 \pm 0,030)$ установлено между показателями молочной продуктивности дочерей за 305 дней первой лактации и уровнем племенной цеенности по надою их отиов, который резко снижался при сравнении их с предками старших поколений.

Сила влияния племенной цеенности предков на удой первотелок уменьшалась с удалением их в поколениях. Сила влияния племенной ценности отцов на абсолютную молочную продуктивность дочерей составляла $35,1 \%$, отџов - отцов - 11,7\%, матерей - 10,6\% и отцов отияов - отиов - $2,7 \%$.

Ключевые слова: бык, родственная группа, племенная ценность, молочная продуктивность, изменчивость, корреляция, наследование, сила влияния

Introduction. The main task of breeding with commercial breeds of cattle at different levels of breeding organization (individual or large-scale) is the constant search for the most valuable genotypes and their maximum use in the population [1-3]. In native science and practice, the main method of improving dairy breeds is breeding for bloodlines [4-23]. The bloodline is understood to mean a genealogically distinct group of animals within a breed that derives from a productive and pedigree breeder, and inherits its traits for generations [10-11].

Bloodline breeding continues to be the only method of preserving the gene pool of small and local breeds, the main task of which is not to maintain the heredity of individual animals but to maintain the genetic diversity of the population [12].

In leading dairy cattle countries in North America and Europe, large-scale breeding is aimed at identifying, by assessing the quality of offspring, and maximizing the use of a limited number of breed-leaders. Due to the fact, that the probability of obtaining bull-improvers with high breeding value (breed leaders) on selected breeding grounds (within $+3 \sigma$ and above) is low enough, according to some foreign and some domestic scientists, breeding along the bloodlines can limit the selection of prominent bulls, and therefore slow down selection [24-27]. 
The success of large-scale breeding based on the use, evaluated by the quality of the offspring, bull-improvers, has caused many foreign and some domestic specialists to have a negative attitude to the traditional breeding method - breeding along the bloodlines [28].

At the same time, the analysis of the gene pool of Holstein breed [29, 31] and the catalogs of Holstein associations of the USA and Canada reveals the saturation of genealogies by the nicknames of breed-leader breeds, the use of different degrees of inbreeding, formation of large groups of related animals.

In this regard, the purpose of our work was to determine the level and variability of indices of primary breeding value based on the milk productivity of bulls of different genealogical groups of US Holstein breeds selected for reproduction, to determine the degree of influence on these traits of their ancestors.

Material and research methods. For the analytical studies, the results of an evaluation of the Holstein proven bulls $(n=372)$ of the United States [31], for the quality of their offspring, selected for reproduction, in 5598 heads, have been evaluated. By genealogy, the bulls were divided into 5 related groups. The breeding value of the bulls of different genealogical groups was analyzed by: milk yield, $\mathrm{kg}$; fat content in milk, \%; amount of milk fat, $\mathrm{kg}$; protein content, \%; amount of milk protein, $\mathrm{kg}$.

Calculation of digital data was carried out by the method of mathematical statistics (correlation, heredity) according to M. A. Plokhinsky, by means of the software package "Statistica-6.1" [30].

Results. The analysis revealed that among the 372 bull-improvers, selected for reproduction, as a result of the initial assessment, 215 heads of them are the sons of 15 bulls-leaders of the breed and belong to 5 genealogical groups (table 1 ).

The largest number (22.8\%), selected for reproduction bulls ( 85 heads) belong to the related group Chief 1427381 and Elevation 1491007 - 54 heads (14.5\%). A slightly smaller number of bullimprovers were received from the sons of the bulls Tradition 1682485 - 39 heads $(10.5 \%)$ and Valiant- 17 heads (4.5\%), who are the followers of the aforementioned related groups.

A statistically significant difference between the breeding value on the basis of milk productivity was found in bulls, recognized as improvers, belonging to different genealogical formations. Breeding value for milk yield, taken from the sons of the related Tradition group was $+803.9 \pm 34.1 \mathrm{~kg}$ of milk and exceeded the group average by $153 \mathrm{~kg}$, which is statistically significant ( $p<0.001$ ), and Bell 67366 was lower average for the group of improvers by $123.0 \mathrm{~kg}(\mathrm{p}<0.1)$. The coefficient of variation of this indicator for Bell's bulls was quite high $(\mathrm{CV}=46.8 \%)$. The breeding value of the fathers and mothers of the bull-improvers of this related group was also lower, than the average of the bulls group, selected for reproduction, which is statistically significant ( $<<0.001$ and $\mathrm{p}<0.1)$.

It was also established, that the breeding value of the animals of the new genealogical formations (sons, fathers, mothers) of Tradition 1682485 and Valiant 1650414 was always higher (on $161.2 ; 121.4 ; 209.4 \mathrm{~kg}$ worth), compared to the older related groups of Elevation and Chief, on which basis they have been formed. This indicates about decreasing of appearance frequency of leader bulls in a single related group during breeding.

A similar predictable of variability of the breeding value of animals of different genealogical formations of the Holstein breed for milk fat and protein in milk was established.

The largest number of sons of dairy performance improvers (milk fat, total protein, and milk yield) were selected for use from the following bulls-improvers of these traits:

- Manfred 218007 (related group Tradition), $(\mathrm{BV}+922+30.4+29.5 \mathrm{~kg})-9$ heads $(2.4 \%$ of the total number of selected bulls for reproduction);

- Mandela 2119528 (related group Valliant), (BV +634 +9.7+16.3) - 8 heads $(2.1 \%)$;

- Rudolf 5470579 (Elevation related group), (BV $+703+17.2+22.2)-30$ heads $(8.0 \%)$;

- Daster 2147486 (Chief related group), (BV $+578+23.0+20.0)-38$ heads $(10.2 \%)$;

- Bell Elton 1912270 (Bell related group), $(\mathrm{BV}+417+14.5+17.6)-17$ heads $(4.6 \%)$, (table 2$)$. 
1. Breeding value of bulls of different genealogical groups of Holstein breed, which are selected for reproduction, and their parents

\begin{tabular}{|c|c|c|c|c|c|}
\hline \multirow{2}{*}{$\begin{array}{l}\text { Genealogical } \\
\text { Group }\end{array}$} & \multirow{2}{*}{$\begin{array}{l}\text { The number of } \\
\text { related } \\
\text { branches in } \\
\text { group }\end{array}$} & \multirow{2}{*}{$\begin{array}{l}\text { The number of } \\
\text { bulls, selected } \\
\text { for reproduction }\end{array}$} & \multicolumn{3}{|c|}{$\begin{array}{l}\text { Breeding value on the basis of milk productivity, } \mathrm{kg} \\
\qquad \mathrm{M} \pm \mathrm{m} / \mathrm{CV}, \%\end{array}$} \\
\hline & & & fathers & mothers & sons \\
\hline \multicolumn{6}{|c|}{ Milk yield } \\
\hline Tradition 1682485 & 3 & 39 & $\begin{array}{c}+710.5 \pm 25.73 * * * \\
22.6 \\
\end{array}$ & $\begin{array}{c}+688.9 \pm 51.76^{*} \\
46.8 \\
\end{array}$ & $\begin{array}{c}+803.9 \pm 34.1 * * * \\
26.5 \\
\end{array}$ \\
\hline Valiant 1650414 & 2 & 17 & $\begin{array}{c}+724.8 \pm 21.35 * * * \\
12.1 \\
\end{array}$ & $\begin{array}{c}+671.2 \pm 65.09 \\
39.9 \\
\end{array}$ & $\begin{array}{l}+762.5 \pm 56.47 \\
30.5\end{array}$ \\
\hline Elevation 1491007 & 4 & 54 & $\begin{array}{c}+501.1 \pm 36.68 \\
53.8\end{array}$ & $\begin{array}{l}+567.5 \pm 31.50 \\
40.5\end{array}$ & $\begin{array}{l}+642.7 \pm 29.34 \\
33.5\end{array}$ \\
\hline Chief 1427381 & 4 & 85 & $\begin{array}{c}+512.5 \pm 8.31 \\
14.9 \\
\end{array}$ & $\begin{array}{l}+583.0 \pm 26.98 \\
42.7\end{array}$ & $\begin{array}{l}+648.9 \pm 23.09 \\
32.8\end{array}$ \\
\hline Bell 67366 & 2 & 20 & $\begin{array}{c}+433.2 \pm 8.58 * * * \\
8.8 \\
\end{array}$ & $\begin{array}{c}+463.2 \pm 49.53 * \\
47.8 \\
\end{array}$ & $\begin{array}{c}+527.9 \pm 55.38 * \\
46.8\end{array}$ \\
\hline $\begin{array}{l}\text { The average through } \\
\text { the bulls, selected } \\
\text { for reproduction }\end{array}$ & & 372 & $\begin{array}{l}+496 \pm 11.75 \\
\quad 45.6\end{array}$ & $\begin{array}{l}+580.3 \pm 14.28 \\
47.5\end{array}$ & $\begin{array}{l}+650.9 \pm 12.44 \\
36.8\end{array}$ \\
\hline \multicolumn{6}{|c|}{ Milkfat } \\
\hline Tradition 1682485 & 3 & 39 & $\begin{array}{c}+8.4 \pm 2.08^{*} \\
70.1\end{array}$ & $\begin{array}{c}+24.9 \pm 2.48 \\
62.2\end{array}$ & $\begin{array}{c}+19.4 \pm 1.73 \\
55.7\end{array}$ \\
\hline Valiant 1650414 & 2 & 17 & $\begin{array}{c}+13.8 \pm 1.13 \\
33.6 \\
\end{array}$ & $\begin{array}{c}+23.9 \pm 2.82 \\
39.9\end{array}$ & $\begin{array}{c}+22.1 \pm 1.58 \\
29.9\end{array}$ \\
\hline $\begin{array}{l}\text { Starbuck } 352790 / \\
\text { Elevation } 1491007\end{array}$ & 4 & 54 & $\begin{array}{c}+15.3 \pm 0.79 * * \\
38.3 \\
\end{array}$ & $\begin{array}{c}+20.1 \pm 1.38 \\
48.5\end{array}$ & $\begin{array}{c}+21.15 \pm 1.28 \\
44.6\end{array}$ \\
\hline Chief 1427381 & 4 & 85 & $\begin{array}{c}+7.3 \pm 0.87^{* * *} \\
72.3 \\
\end{array}$ & $\begin{array}{c}+22.4 \pm 1.29 \\
53.3\end{array}$ & $\begin{array}{c}+17.1 \pm 0.93 * * * \\
50.4\end{array}$ \\
\hline Bell 67366 & 2 & 20 & $\begin{array}{c}+16.9 \pm 1.35 * * \\
35.2\end{array}$ & $\begin{array}{c}+19.9 \pm 2.15 \\
48.3 \\
\end{array}$ & $\begin{array}{c}+21.6 \pm 1.98 \\
40.9\end{array}$ \\
\hline $\begin{array}{l}\text { The average through } \\
\text { the bulls, selected } \\
\text { for Reproduction }\end{array}$ & & 372 & $\begin{array}{c}+12.8 \pm 0.49 \\
73.1\end{array}$ & $\begin{array}{c}+21.8 \pm 0.61 \\
54.0\end{array}$ & $\begin{array}{c}+20.9 \pm 0.47 \\
28.6\end{array}$ \\
\hline \multicolumn{6}{|c|}{ Total protein in milk } \\
\hline Tradition 1682485 & 3 & 39 & $\begin{array}{c}+16.9 \pm 1.15 \\
42.7\end{array}$ & $\begin{array}{c}+23.9 \pm 1.59 \\
41.6\end{array}$ & $\begin{array}{c}+22.9 \pm 1.08 \\
29.6\end{array}$ \\
\hline Valiant 1650414 & 2 & 17 & $\begin{array}{c}+18.2 \pm 0.45 * * * \\
10.3\end{array}$ & $\begin{array}{c}+22.3 \pm 1.85 \\
34.1\end{array}$ & $\begin{array}{c}+21.7 \pm 1.49 \\
28.4\end{array}$ \\
\hline $\begin{array}{l}\text { Starbuck } 352790 / \\
\text { Elevation } 1491007\end{array}$ & 4 & 54 & $\begin{array}{c}+17.2 \pm 0.94 \\
40.2 \\
\end{array}$ & $\begin{array}{c}+19.9 \pm 0.86 \\
31.6 \\
\end{array}$ & $\begin{array}{c}+20.7 \pm 0.66 \\
23.7 \\
\end{array}$ \\
\hline Chief 1427381 & 4 & 85 & $\begin{array}{c}+16.8 \pm 0.47 \\
26.1\end{array}$ & $\begin{array}{c}+20.8 \pm 0.76 \\
34.7\end{array}$ & $\begin{array}{c}+19.6 \pm 0.61 \\
28.9\end{array}$ \\
\hline Bell 67366 & 2 & 20 & $\begin{array}{c}+18.3 \pm 0.41 * * * \\
9.9\end{array}$ & $\begin{array}{c}+18.8 \pm 1.30 \\
31.0\end{array}$ & $\begin{array}{c}+21.0 \pm 1.22 \\
26.0\end{array}$ \\
\hline $\begin{array}{l}\text { The average through } \\
\text { the bulls, selected } \\
\text { for reproduction }\end{array}$ & & 372 & $\begin{array}{c}+16.4 \pm 0.35 \\
38.1\end{array}$ & $\begin{array}{c}+20.7 \pm 0.40 \\
37.3\end{array}$ & $\begin{array}{c}+20.9 \pm 0.31 \\
28.6\end{array}$ \\
\hline
\end{tabular}

The sons of these bulls inherit the signs of milk productivity, their breeding value exceeded that of their parents: by milk fat - by $2.4-20.0 \mathrm{~kg}$, total protein - by $0.7-11.8 \mathrm{~kg}$. The absolute milk production of their daughters in the 305 days of the first lactation was $11201-13173 \mathrm{~kg}$ of milk, $411-$ $475 \mathrm{~kg}$ of milk fat and $337-383 \mathrm{~kg}$ of total protein, which exceeded the productivity of their contemporarys by $113-1025 \mathrm{~kg}$ of milk, $8.6-55.6 \mathrm{~kg}$ milk fat and $9.3-30.3 \mathrm{~kg}$ total protein.

From the 25 bulls $(0.375 \%$ of all estimated), which have been selected it to the top $5 \%$ for breeding value from dairy productivity -17 heads $(68.0 \%)$ are the sons of the ancestors of the aforementioned related groups, which provide genetic progress of the breed, and, in our understanding, are the bloodlines. 
2. Breeding value of bulls of different related groups, selected for reproduction and their daughters' milk productivity

\begin{tabular}{|c|c|c|c|c|c|c|c|c|c|c|}
\hline \multirow{2}{*}{$\begin{array}{l}\text { Number of } \\
\text { sons, } \\
\text { by rank for } \\
\text { milk yield }\end{array}$} & \multicolumn{5}{|c|}{ Breeding value of sons } & \multicolumn{5}{|c|}{ Dairy performance of daughters } \\
\hline & $\begin{array}{c}\text { milk } \\
\text { yield, } \\
\text { kg }\end{array}$ & $\begin{array}{c}\text { fat } \\
\text { content, } \%\end{array}$ & $\begin{array}{c}\text { milk } \\
\text { fat, } \mathrm{kg}\end{array}$ & $\begin{array}{c}\text { protein } \\
\text { content, } \%\end{array}$ & $\begin{array}{c}\text { total } \\
\text { protein, } \\
\text { kg }\end{array}$ & $\begin{array}{c}\text { milk } \\
\text { yield, kg }\end{array}$ & $\begin{array}{c}\text { fat } \\
\text { content, \% }\end{array}$ & $\begin{array}{c}\text { milk } \\
\text { fat, } \mathrm{kg}\end{array}$ & $\begin{array}{c}\text { protein } \\
\text { content } \%\end{array}$ & $\begin{array}{c}\text { total } \\
\text { protein, } \\
\mathrm{kg}\end{array}$ \\
\hline \multicolumn{11}{|c|}{ Related Tradition group $\rightarrow$ father Manfred $218007(B V+922+30.4+29.5)$} \\
\hline 9 & +902 & -0.05 & +30.8 & +0.01 & +27.9 & 12114 & 3.70 & 447.0 & 3.01 & 364.0 \\
\hline 1 st in rank & +801 & +0.12 & +44.5 & -0.06 & +34.4 & 13173 & 3.56 & 470.0 & 2.87 & 378.0 \\
\hline 9th in rank & +780 & -0.10 & +16.5 & -0.04 & +18.6 & 11875 & 3.58 & 425.0 & 2.94 & 350.0 \\
\hline $\begin{array}{l}\text { Ratio to all } \\
\text { group, } \%\end{array}$ & 138.7 & & 142.8 & & 128.5 & 102.5 & 101.7 & 104.1 & 94.9 & 102.2 \\
\hline \multicolumn{11}{|c|}{ Related Elevation group $\rightarrow$ father Rudolf $5470579(B V+703+17.2+22.2)$} \\
\hline 30 & +714 & -0.04 & +20.0 & +0.01 & +22.1 & 11906 & 3.59 & 427.6 & 3.02 & 357.0 \\
\hline 1 st in rank & +1113 & -0.08 & +31.3 & +0.02 & +35.4 & 12394 & 3.52 & 434.0 & 2.99 & 368.0 \\
\hline 30th in rank & +352 & -0.09 & +2.3 & -0.02 & +8.6 & 11542 & 3.78 & 436.0 & 3.10 & 358.0 \\
\hline $\begin{array}{l}\text { Ratio to all } \\
\text { group, } \%\end{array}$ & 109.8 & & 95.2 & & 104.7 & 100.8 & 98.7 & 99.5 & 100.1 & 100.2 \\
\hline \multicolumn{11}{|c|}{ Related group Valiant $\rightarrow$ father Mandel $2119528(B V+634+9.7+16.3)$} \\
\hline 8 & +683 & -0.03 & +21.0 & -0.03 & +21.4 & 11953 & 3.61 & 430.0 & 3.02 & 361.0 \\
\hline 1 st in rank & +1011 & -0.08 & +29.0 & +0.03 & +34.9 & 12400 & 3.60 & 446.0 & 3.02 & 376.0 \\
\hline 8th in rank & +234 & -0.03 & +5.4 & +0.04 & +10.8 & 11720 & 3.71 & 435.0 & 3.06 & 358.0 \\
\hline $\begin{array}{l}\text { Ratio to all } \\
\text { group, } \%\end{array}$ & 105.0 & & 100.0 & & 101.9 & 101.2 & 99.2 & 100.2 & 100.1 & 101.4 \\
\hline \multicolumn{11}{|c|}{ Related Chief's group $\rightarrow$ father Duster $2147486(B V+578+23.0+20.0)$} \\
\hline 38 & +653 & -0.08 & +12.4 & +0.06 & +20.7 & 11698 & 3.55 & 415.0 & 3.01 & 357.0 \\
\hline $1 \mathrm{st}$ in rank & +1051 & -0.01 & +27.2 & +0.01 & +32.6 & 11732 & 3.60 & 422.0 & 3.03 & 346.0 \\
\hline 38th in rank & +304 & +0.12 & +2.3 & +0.02 & +14.1 & 11397 & 3.78 & 435.0 & 3.08 & 351.0 \\
\hline $\begin{array}{l}\text { Ratio to all } \\
\text { group, } \%\end{array}$ & 100.4 & & 59.0 & & 98.6 & 99.0 & 97.6 & 96.7 & 99.7 & 100.2 \\
\hline \multicolumn{11}{|c|}{ Related Bella's group $\rightarrow$ father of Bell Elton $1912270(B V+417+14.5+17.6)$} \\
\hline 17 & +485 & -0.03 & +20.5 & +0.04 & +19.8 & 11719 & 3.71 & 434.0 & 3.06 & 356.0 \\
\hline 1 st in rank & +754 & -0.04 & +30.9 & -0.01 & +26.3 & 12758 & 3.72 & 475.0 & 3.00 & 383.0 \\
\hline 17 th in rank & +338 & -0.11 & +0 & +0.09 & +19.5 & 11994 & 3.43 & 411.0 & 2.82 & 337.0 \\
\hline $\begin{array}{l}\text { Ratio to all } \\
\text { group, } \%\end{array}$ & 74,6 & & 97,6 & & 94,2 & 99,2 & 102,2 & 101,2 & 101,4 & 100,0 \\
\hline \multicolumn{11}{|c|}{ Other related Blackstar groups $\rightarrow$ Sally $123963651(B V+29+17.0+10.0)$} \\
\hline 1 & +197 & $+0,19$ & +28 & $+0,11$ & $+16,4$ & 11317 & 3,92 & 443,0 & 3,11 & 351 \\
\hline $\begin{array}{l}\text { Ratio to all } \\
\text { group, } \%\end{array}$ & 30,3 & & 133,3 & & 78,0 & 95,8 & 107,7 & 103,2 & 103,8 & 98,6 \\
\hline \multicolumn{11}{|c|}{ Related Gibbon group $17156150 \rightarrow$ Fucheland $12439808(B V+29+17.0+10.0)$} \\
\hline & -93 & +0.26 & +31.0 & +0.13 & +16.4 & 11201 & 4.12 & 462.0 & 3.14 & 352 \\
\hline $\begin{array}{l}\text { Ratio to all } \\
\text { group, } \%\end{array}$ & 0.1 & & 147.6 & & 76.2 & 94.8 & 113.2 & 107.6 & 104.0 & 98.8 \\
\hline \multicolumn{11}{|c|}{ Related Blackstar group $\rightarrow$ Star Journalist 2261753} \\
\hline & -14 & +0.24 & +25.0 & +0.06 & +6.0 & 11202 & 3.89 & 436.0 & 3.07 & 343 \\
\hline $\begin{array}{l}\text { Ratio to all } \\
\text { group, } \%\end{array}$ & 0.15 & & 119.0 & & 28.5 & 94.8 & 107.2 & 101.6 & 101.7 & 96.3 \\
\hline
\end{tabular}

High correlation between breeding value`s level of milk yield, milk fat and protein of parents and their sons was identified. The highest correlation coefficient $(r=+0.643 \pm 0.030)$ was established between the dairy productivity of daughters for 305 days of first lactation and the level of breeding value at their fathers' milk yield, which decreased sharply, when compared with their ancestors from older generations.

The power of the influence of ancestral breeding value on the milk yield of the firstcalve cows decreased with the removal of them in generations.

The level of breeding value of the fathers has the greatest influence on the level of milk production of their daughters of the Holstein breed (the influence force is $35.1 \%$ ) (table 3 ). 
3. The influence of parental breeding value on dairy productivity their daughters in 305 days of first lactation

\begin{tabular}{|l|c|c|c|c|}
\hline \multirow{2}{*}{\begin{tabular}{c}
\multirow{2}{*}{$\begin{array}{c}\text { Factor } \\
\text { (breeding value) }\end{array}$} \\
\cline { 2 - 5 }
\end{tabular}} & number of gradations & $\begin{array}{c}\text { number of the } \\
\text { complex }\end{array}$ & $\eta_{x}^{2} \pm \mathrm{m}_{\eta}^{2}$ & $\mathrm{~F}_{\eta \times}^{2}$ \\
\hline Father & 7 & 137 & $0.351 \pm 0.0299$ & $11.74^{*} * *$ \\
\hline The father - father & 8 & 136 & $0.117 \pm 0.0428$ & $2.84^{*}$ \\
\hline Mother & 7 & 828 & $0.106 \pm 0.0415$ & $2.55^{*}$ \\
\hline $\begin{array}{l}\text { Father }- \text { father }- \\
\text { father }\end{array}$ & 6 & 204 & $0.027 \pm 0.0245$ & 1.08 \\
\hline
\end{tabular}

In second place was the force of influence breeding value of the father-fathers on the milk yield of firstborn cows, which was $11.7 \%$. The third place was occupied by the influence of the breeding value of mothers on the level of milk productivity of daughters $\left(\eta^{2} x=10.6 \%\right)$. These forces of influence of these ancestors on the level of milk productivity of the firstborn cows are statistically significant $(\mathrm{P}<0.05-0.001)$.

The last place of force of influence $\left(\eta^{2}\right)$ on the level of milk productivity of the cows take the male ancestors, who are in their third line of pedigree (FFF), it was $2.7 \%$ and was not statistically significant.

Conclusions. The statistically significant variability of the breeding value indices for the milk productivity of the bulls and their parents of different genealogical formations of the Holstein breed was established. Breeding value based on the milk productivity of animals of new genealogical formations (sons, parents, mothers), selected for reproduction, was higher than in older related groups (in our sense, the bloodlines) on which they have been formed. This indicates, that the likelihood of obtaining the bulls with high breeding value (breed-leaders) is decreasing among older genealogical groups of animals. The power of the influence of ancestral breeding value on the milk yield of the firstborn cows decreased with the removal of them in generations.

\section{BIBLIOGRAPHY}

1. Крупномасштабная селекция в животноводстве / Н. 3. Басовский, В. П. Буркат, В. И. Власов, В. П. Коваленко. - К. : Асоціація «Україна». - 1994. - 360 с.

2. Розведення сільськогосподарських тварин / М. 3. Басовський, В. П. Буркат, Д. Т. Вінничук, В. П. Коваленко, М. С. Ківа, Ю. Д. Рубан, І. А. Рудик, Й. З. Сірацький. - Біла Церква, 2001. $-400 \mathrm{c}$.

3. Эйснер, Ф. Ф. Племенная работа с молочным скотом / Ф. Ф. Эйснер. - М. : Агропромиздат, 1986. - $184 \mathrm{c.}$

4. Абрамова, Н. И. Характеристика современной популяции крупного рогатого скота айрширской породы Вологодской области с учетом генеалогической принадлежности / Н. И. Абрамова, Г. С. Власова, Л. Н. Богорадова // Молочное и мясное скотоводство. - 2018. - № 3. C. 21-24.

5. Кравченко, Н. А. Племенной подбор при разведении по линиям / Н. А. Кравченко. - М. : Госсельхозиздат, 1954. - 264 с.

6. Буркат, В. П. Генезис понять і методів та сучасний селекційний контекст розведення тварин за лініями / В. П. Буркат, Ю. П. Полупан // Розведення і генетика тварин. - Київ : Аграр. наука, 2005. - С. 3-36.

7. Кругляк, А. П. Шляхи генетичного удосконалення та консолідації української червонорябої молочної породи / А. П. Кругляк // Розведення і генетика тварин. - Київ, 1996. - Вип. 28. - C. 83-89.

8. Положення з проведення апробації селекційних досягнень у тваринництві : зареєстровано в Міністерстві юстиції України 19 липня 2012 р. за № 1217/21529. - Режим доступу : https://zakon.rada.gov.ua/laws/show/z1217-12.

9. Підпала, Т. В. Великомасштабна селекція і розведення за лініями / Т. В. Підпала // Розведення і генетика тварин. - Київ, 2005. - Вип. 38. - С. 107-111.

10. Зубець, М. В. Вчення про породу у скотарстві / М. В. Зубець // Вибрані твори. - Київ : 
Аграр. наука, 2003. - С. 128-143.

11. Рубан, Ю. Д. Теорія і практика розведення великої рогатої худоби за лініями / Ю. Д. Рубан // Розведення і генетика тварин. - Київ, 2005. - Вип. 38. - С. 91-96.

12. Прожерин, В. П. Проблемы сохранения генофонда отечественных пород молочного скота / В. П. Прожерин, В. Л. Ялуга, Л. А. Калашникова // Зоотехния. - 2016. - № 9. - С. $2-4$.

13. Князева, Т. А. Совершенствование генеалогической структуры линий и родственных групп красных молочных пород / Т. А. Князева, Н. Ю. Чекменева // Зоотехния. - 2017. - № 2. - C. 8-10.

14. Рыжова, Н. Г. Генетическая характеристика генеалогической структуры красно-пестрой породы крупного рогатого скота / Н. Г. Рыжова // Зоотехния. - 2017. - № 2. - С. 10-13.

15. Самусенко, Л. Д. Генеалогические линии как биологические ресурсы молочного скотоводства / Л. Д. Самусенко, С. Н. Химичева // Зоотехния. - 2018. - № 6. - С. 7-11.

16. Руденко, О. В. Продуктивное долголетие красных горбатовских коров в зависимости от их линейной принадлежности / О. В. Руденко, Н. П. Шкилев // Зоотехния. - 2018. - № 11. С. 8-10.

17. Молочная продуктивность коров австралийской селекции разной линейной принадлежности / И. Ф. Горлов, Е. Ю. Злобина, А. А. Кайдулина, Т. Н. Бармина, С. А. Суркова, Д. А. Мосолова // Молочное и мясное скотоводство. - 2019. - № 7. - С. 27-30.

18. Молочная продуктивность голштинских коров различных линий / А. А. Мишхожев, 3. М. Айсанов, Т. Т. Тарчоков, М. Г. Тлейншева // Зоотехния. - 2017. - № 9. - С. 2-5.

19. Кертиев, Р. М. Генеалогическая структура быков-производителей холмогорской породы / Р. М. Кертиев, В. М. Высоцкая // Зоотехния. - 2017. - № 2. - С. 13-15.

20. Даниленко, О.В.Эффективность использования быков-улучшателей аулиекольского скота и различных типов подбора в племенных стадах / О. В. Даниленко // Зоотехния. - 2017. - № 8. - С. 6-10.

21. Акимбеков, А. Р. Продуктивность казахских лошадей типа жабе при разведении по линиям / А. Р. Акимбеков, Ю. А. Юлдашбаев // Зоотехния. - 2017. - № 5. - С. 11-13.

22. Абрамова, Н. И. Совершенствование генеалогической структуры популяции крупного рогатого скота черно-пестрой породы племенных хозяйств Вологодской области / Н. И. Абрамова // Зоотехния. - 2016. - № 6. - С. 2-4.

23. Новый подход к оценке линий молочного скота с учетом коэффициента линейности / Н. И. Абрамова, Л. Н. Богорадова, Г. С. Власова, О. Л. Хромова, О. Н. Бургомистрова, К. А. Задумкин // Зоотехния. - 2018. - № 9. - С. 2-6.

24. Кузнецов, В. М. Разведение по линиям и голштинизация: методы оценки, состояние и перспективы / В. М. Кузнецов // Проблемы биологии продуктивных животных. - 2013. - № 3. - C. 25-79.

25. Багрий, Б. Проблемы использования генетических ресурсов в скотоводстве / Б. Багрий // Молочное и мясное скотоводство. - 1982. - № 12. - С. 30-35.

26. О разведении молочного скота по линиям / А. П. Бегучев, М. Д. Дедов, Д. В. Карликов, В. И. Бронский, М. Г. Спивак, Ю. П. Тимофеев, А. Б. Котлова, Н. Ф. Лось // Животноводство. - 1982. - № 8. - С. 61-64.

27. Чехівський, М. Й. Про неприйнятність лінійного розведення великої рогатої худоби / М. Й. Чехівський // Розведення і генетика тварин. - Київ : Аграр. наука. - Вип. 38. - С. 116118.

28. Борисовський, В. А. Продуктивні якості корів айрширського стада залежно від їх лінійної належності / В. А. Борисовський // Науково-технічний бюлетень / Інститут тваринництва УААН. - Харків, 2008. - № 97. - С. 190-194.

29. Генофонд голштинского скота в Украине / А. П. Кругляк, В. П. Буркат, А. Ф. Хаврук, Л. С. Кругляк. - Киев : Урожай, 1994. - 387 с.

30. Плохинский, Н. А. Руководство по биометрии для зоотехников / Н. А. Плохинский. - М. : Колос, 1969. - 259 с. 
31. Sire Summaries / Holstein Association USA. - May 2003. - 181 p.

\section{REFERENCES}

1. Basovskiy, N. Z., V. P. Burkat, V. I. Vlasov, and V. P. Kovalenko. 1994. Krupnomasshtabnaya selektsiya $v$ zhivotnovodstve - Large-scale breeding in livestock. K.: Asotsiatsiya «Ukrayina», 360 (in Ukrainian).

2. Basovskyi, M. Z., V. P. Burkat, D. T. Vinnychuk, V. P. Kovalenko, M. S. Kiva, Yu. D. Ruban, I. A. Rudyk, and Y. Z. Siratskyi. 2001. Rozvedennia silskohospodarskykh tvaryn - Breeding farm animals. - Bila Tserkva, 400 (in Ukrainian).

3. Eysner, F. F. 1986. Plemennaya rabota s molochnym skotom-Breeding work with dairy cattle. M. : Agropromizdat, 184 (in Russian).

4. Abramova, N. I., G. S. Vlasova, and L. N. Bogoradova. 2018. Kharakteristika sovremennoy populyatsii krupnogo rogatogo skota ayrshirskoy porody Vologodskoy oblasti s uchetom genealogicheskoy prinadlezhnosti - Characterization of the modern population of cattle of Ayrshire breed of the Vologda region, taking into account the genealogical affiliation. Molochnoe $i$ myasnoe skotovodstvo - Dairy and beef cattle breeding. 3:21-24 (in Russian).

5. Kravchenko, N. A. 1954. Plemennoy podbor pri razvedenii po liniyam - Tribal selection for line breeding. M. Gossel'khozizdat, 264 (in Russian).

6. Burkat, V. P., and Yu. P. Polupan. 2005. Henezys poniat i metodiv ta suchasnyi selektsiinyi kontekst rozvedennia tvaryn za liniiamy - Genesis of concepts and methods and modern breeding context for breeding animals along the lines. Rozvedennia i henetyka tvaryn-Animal Breeding and Genetics. 38:3-36 (in Ukrainian).

7. Kruhliak, A. P. 1996. Shliakhy henetychnoho udoskonalennia ta konsolidatsii ukrainskoi chervono-riaboi molochnoi porody - Ways of Genetic Improvement and Consolidation of Ukrainian red-and-white dairy breeds. Rozvedennia i henetyka tvaryn-Animal Breeding and Genetics. 28:8389 (in Ukrainian).

8. Polozhennia pro aprobatsiiu selektsiinykh dosiahnen $u$ tvarynnytstvi - Provisions on the approbation of breeding achievements in animal husbandry. K. : 19 lypnia 2012, 17 (in Ukrainian).

9. Pidpala, T. V. 2005. Velykomasshtabna selektsiia i rozvedennia za liniiamy - Large-scale breeding and line breeding. Rozvedennia i henetyka tvaryn - Animal Breeding and Genetics. 38:107111 (in Ukrainian).

10. Zubets, M. V. 2003. Vchennia pro porodu u skotarstvi. Vybrani tvory - The doctrine of breed in cattle breeding. Selected works. K. : Ahrarna nauka, 128-143 (in Ukrainian).

11. Ruban, Yu. D. 2005. Teoriia i praktyka rozvedennia velykoi rohatoi khudoby za liniiamy Theory and practice of cattle breeding. Rozvedennia i henetyka tvaryn - Animal Breeding and Genetics. 38:91-96 (in Ukrainian).

12. Prozherin, V. P., V. L. Yaluga, and L. A. Kalashnikova. 2016. Problemy sokhraneniya genofonda otechestvennykh porod molochnogo skota - Problems of preserving the gene pool of domestic breeds of dairy cattle. Zootekhniya - Livestock. 9:2-4 (in Russian).

13. Knyazeva, T. A., and Yu. Chekmeneva. 2017. Sovershenstvovanie genealogicheskoy struktury liniy i rodstvennykh grupp krasnykh molochnykh porod - Improving the genealogical structure of lines and related groups of red dairy breeds. Zootekhniya-Livestock. 2:8-10 (in Russian).

14. Ryzhova, N. G. 2017. Geneticheskaya kharakteristika genealogicheskoy struktury krasnopestroy porody krupnogo rogatogo skota - Genetic characteristics of the genealogical structure of red-motley cattle. Zootekhniya - Livestock. 2:10-13 (in Russian).

15. Samusenko, L. D., and S. N. Khimicheva. 2018. Genealogicheskie linii kak biologicheskie resursy molochnogo skotovodstva - Genealogical lines as biological resources of dairy cattle breeding. Zootekhniya-Livestock. 6:7-11 (in Russian).

16. Rudenko, O. V., and N. P. Shkilev. 2018. Produktivnoe dolgoletie krasnykh gorbatovskikh korov v zavisimosti ot ikh lineynoy prinadlezhnosti - Productive longevity of red humpback cows depending on their linear affiliation. Zootekhniya-Livestock. 11:8-10 (in Russian). 
17. Gorlov, I. F., E. Yu. Zlobina, A. A. Kaydulina, T. N. Barmina, S. A. Surkova, and D. A. Mosolova. 2019. Molochnaya produktivnost' korov avstraliyskoy selektsii raznoy lineynoy prinadlezhnosti - Milk productivity of Australian cows of different linear affiliation. Molochnoe $i$ myasnoe skotovodstvo - Dairy and beef cattle breeding. 7:27-30 (in Russian).

18. Mishkhozhev, A. A., Z. M. Aysanov, T. T. Tarchokov, and M. G. Tleynsheva. 2017. Molochnaya produktivnost' golshtinskikh korov razlichnykh liniy - Milk productivity of Holstein cows of various lines. Zootekhniya - Livestock. 9:2-5 (in Russian).

19. Kertiev, R. M., and V. M. Vysotskaya. 2017. Genealogicheskaya struktura bykovproizvoditeley kholmogorskoy porody - Genealogical structure of Kholmogorsk breed bulls. Zootekhniya-Livestock. 2:13-15 (in Russian).

20. Danilenko, O. V. 2017. Effektivnost' ispol'zovanya bykov-uluchshateley auliekol'skogo skota i razlichnykh tipov podbora $v$ plemennykh stadakh - Efficiency of using improvement bulls of Auliekol cattle and various types of selection in breeding herds. Zootekhniya - Livestock. 8:6-10 (in Russian).

21. Akimbekov, A. R., and Yu. A. Yuldashbaev. 2017. Produktivnost' kazakhskikh loshadey tipa zhabe pri razvedenii po liniyam - The productivity of Kazakh horses of the toad type when breeding along the lines. Zootekhniya - Livestock. 5:11-13 (in Russian).

22. Abramova, N. I. 2016. Sovershenstvovanie genealogicheskoy struktury populyatsii krupnogo rogatogo skota cherno-pestroy porody plemennykh khozyaystv Vologodskoy oblasti - Improving the genealogical structure of the population of cattle of black-and-white dairy breeds of pedigree farms of the Vologda region. Zootekhniya - Livestock. 6:2-4 (in Russian).

23. Abramova, N. I., L. N. Bogoradova, and G. S. Vlasova O. L. Khromova, O. N. Burgomistrov, and K. A. Zadumkin. 2018. Novyy pokhod k otsenke liniy molochnogo skota s uchetom koefitsienta lineynosti - A new approach to the assessment of dairy cattle lines taking into account the linearity coefficient. Zootekhniya - Livestock. 9:2-6 (in Russian).

24. Kuznetsov, V. M. 2013. Razvedenie po liniyam i golshtinizatsiya: metody otsenki, sostoyanie i perspektivy - Line breeding and Holsteinization: assessment methods, status and prospects. Problemy biologii produktivnikh zhivotnykh - Problems of biology of productive animals. 3:25-79 (in Russian).

25. Bagriy, B. 1982. Problemy ispol'zovaniya geneticheskikh resursov v skotovodstve - Problems of the use of genetic resources in livestock. Molochnoe i myasnoe skotovodstvo - Dairy and beef cattle breeding. 12:30-35 (in Russian).

26. Beguchev, A. P., $\quad$ M. D. Dedov, D. V. Karlikov. V. I. Bronsky, M. G. Spivak, Yu. P. Timofeev, A. B. Kotlova, and N. F. Los'. 1982. O razvedenii molochnogo skota po liniyam On breeding dairy cattle on the lines. Zhivotnovodstvo - Animal husbandry. 8:61-64 (in Russian).

27. Chekhivskyi, M. Y. 2005. Pro nepryiniatnist liniinoho rozvedennia velykoi rohatoi khudoby The inadmissibility of linear breeding of cattle. Rozvedennia $i$ henetyka tvaryn - Animal Breeding and Genetics. 38:116-118 (in Ukrainian).

28. Borysovskyi, V. A. 2008. Produktyvni yakosti koriv airshyrskoho stada zalezhno vid yikh liniinoi nalezhnosti - The productive qualities of the Ayrshire herd cows depending on their lineage. Naukovo-tekhnichnyi biuleten Instytutu tvarynnytstva UAAN. - Scientific and Technical Bulletin of the Institute of Animal Breeding of UAAS. Kharkiv, 97:190-194 (in Ukrainian).

29. Kruglyak, A. P., V. P. Burkat, A. F. Khavruk, and L. S. Kruglyak. 1994. Genofond golshtinskogo skota v Ukraine - Holstein cattle gene pool in Ukraine. Kiev, «Urozhay», 387 (in Ukrainian).

30. Plokhinskiy, N. A. 1969. Rukovodstvo po biometrii dlya zootekhnikov-Biometrics Guide for Livestock Specialists. M. : Kolos, 259 (in Ukrainian).

31. Sire Summaries / Holstein Association USA. - May 2003. - 181 (in English).

Одержано редколегією 24.04.2020 р.

Прийнято до друку 30.04.2020 p. 